2020, Volume 14, International Conference Innovative Business Management \& Global Entrepreneurship (IBMAGE 2020), pages: 349-368 |

https://doi.org/10.18662/lumproc/ibmage2020/26

\section{How Environmental Performance Influences SMEs' Competitive Performance: A Case of Food Production Industry}

\section{Duangporn PUT'TAWONG1, Anusorn KUNANUSORN2*}

${ }^{1}$ Rajamangala University of Technology Thanyaburi, Pratumthani, Thailand, dputtawong@gmail.com

${ }^{2}$ Rajamangala University of Technology Lanna, Chiang Mai, Thailand, a kunanusorn@hotmail.com * Corresponding author
Abstract: This research studies the effects of environmental performance, green corporate image, and corporate competitive performance on the food production industry in the Bangkok Metropolitan area. Using a multistage sampling method, 400 questionnaires were distributed by mail to SMEs in the food production industry with a response rate of 94.5 percent. Data was analyzed by structural equation modeling using the AMOS program to evaluate the significance of relationships between environmental performance, green corporate image, and corporate competitive performance. Environmental performance, an antecedent variable, was found to have a very moderate positive indirect effect on corporate competitive performance via green corporate image. Sixty-four percent of the variation in the dependent variable is explained by the antecedent variables, indicating significant mediating effects on marketing performance of SMEs in the food industry. Corporate competitive performance was found to be directly affected by corporate environmental performance, suggesting the industry would benefit from increased concern with environmental performance.

Keywords: Environmental Performance, Green Corporate Image, Corporate Competitive Performance, SMEs, Food Production Industry.

How to cite: Puttawong, D., \& Kunanusorn, A. (2020). How Environmental Performance Influences SMEs' Competitive Performance: A Case of Food Production Industry. In M. W. Staniewski, V. Vasile, \& A. Grigorescu (vol. ed.), Lumen Proceedings: Vol. 14. International Conference Innovative Business Management \& Global Entrepreneurship (IBMAGE 2020) (pp. 349-368). Iasi, Romania: LUMEN Publishing House. https://doi.org/10.18662/lumproc/ibmage2020/26 


\section{Introduction}

Economic progress and technological development have had a significant direct effect on the rapid development of production of goods and services in Thailand and, in the process, have increased natural resource consumption, especially in the food production industry. At the same time, fast growth and rapid development have also created environmental problems in form of air pollution, water pollution, soil pollution, and sound pollution. That rapid development impacts world climate, where climate change and global warming are having negative effects on ecological diversity. Additionally, production processes used by the food industry create toxicity problems as the industrial processes which transform agricultural products also create waste and left-over materials.

With abundant natural resources and significant growth in technology, Thailand is one of the world's largest producers of food products. Thailand has long been called "the kitchen of the world", with food products contributing roughly $23 \%$ of the country's GDP and a food trade balance at a record value of USD 16.7 billion in 2016 [52]. Thus, the food production industry is of fundamentally significant export value to the Thai economy. The industry has shown a tendency to grow in both the short term and the long term [4]. Export statistics show a significant increase in the value of exports of the food production industry. If growth continues at the current pace, food production in the absence of proper environmental management has the potential to damage the Thai environment as well as to resulting in other externalities, e.g., negative impacts on human health, increased pollution, and contaminated natural resources.

Pollution problems are a concern to all and are a burden to remedy. Environmental pollution impacts the corporate competitive strategy of business organizations [11]. A comparative study of more than 2,500 companies around the world conducted by the Dow Jones Company [53] reported that businesses which emphasized and were regularly involved with corporate social responsibility (CSR) constantly had a higher financial growth rate than other businesses. Dow Jones Industrial Average data have confirmed that businesses with CSR programs and appropriate environmental performance have invested more funds in environmental programs in past few years [10].

Today, growth of businesses requires proper resource management including increased recognition of the value of and concern for the environment. Academic studies have identified a positive correlation between competitive advantage and environmental performance of 
organizations [11], [25]; [27]; [30]; [34]. Moreover, corporate environmental performance has also been shown to impact directly on the competitive advantage of an organization as well as having an indirect impact via the public image and goodwill of the organization [13]; [30] [37]. Increase awareness of the impact of environmental performance on the corporate image and goodwill of an organization as viewed by customers and stakeholders can create a competitive advantage for a business organization.

\section{Problem Statement}

Ninety percent of the food industry businesses in Thailand are classified as SMEs, and $95.60 \%$ are small factories with an investment of less than 350,000 USD [4]. However, some of those factories do not pay sufficient attention to the quality of the production process and minimizing the impact on the environment. If entrepreneurs in the food industry had greater concern about environmental problems, they would gain an advantage in terms of market enlargement over their competitors which have a poor environmental performance. Organizations which have good CSR maintain a good image in the eyes of their customers and stakeholders. Their environmental concern activities enhance their corporate image, and customers tend to prefer to purchase products from environmentally concerned organizations [25]. Consumers have their rights and tend to purchase products from businesses that have a greater concern for consumer safety which is one of the 8 rights of the consumers. Businesses which carrying good image will publicize their performances and also employ the image as a marketing public advertising [55]. There is increasing social pressure on the public sector, state enterprises, local governments, and the private sector regarding environmental concerns and the relationship between a healthy environment and quality of life. The business sector must maintain goodwill based on ethical standards which indicate a standard of operation which reflects an obligation to society. Organizations can make environmental performance part of their corporate strategy, and thus increasing their competitive advantage. However, because organizational resources are limited, environmental performance must be balanced with efforts to maximize benefits to the organization, to society, and to the economy of the nation at large.

Competition among SMEs is affected by the relationship between environmental performance and production efficiency. Organizations seek a balance among environmental performance, the green image of the organization, and competitive performance. Structural equation modelling of those variables can be used to examine the relationships among them. In this 
study, SMEs in the food industry in the Bangkok metropolitan area were used to test this model. Results of the study could help in planning proper management of resources and economically pairing that with environmental preservation, providing both economic benefits and improving the image of the organization while simultaneously benefitting the local community and society at large, reducing the cost of operation, and helping to preserve the environment.

\section{Research Questions, Aims of the research and Research Framework}

\subsection{Conceptual Framework and Environmental Performance Theory}

\section{Definition of Environmental Performance}

Concern about the environment has been a major social issue for a number of years. Businesses around the world are increasingly pressured by stakeholders to be socially responsible. Working closely with environment is a major objective. Management has been pressured to consume resources efficiently and to minimize impacts on the environment, e.g., the greenhouse effect, water and air pollution [42]. The International Organization for Standardization (ISO) developed ISO 26000 [16] which contains 7 core subjects of social responsibility, one of which is environmental standards which firms can follow, including a strategy for environmental preservation, standards for consumption of natural resources, activities for environmental preservation, and standards for managerial minimization of negative impacts on the environment.

Environmental management is a main objective of stakeholders, both inside and outside business, especially SMEs, as proper management of the environment is directly beneficial to them. Business environmental management is employed as a business strategy of which must be higher effectiveness than competitors. Results of a survey found that competitive advantage is a major motivator driving business toward ecological and environmental social responsibility [42]. Moreover, environmental practices, derived from environmental management, also affect economic performance [8] [44].

Business outcomes are affected by environmental performance, e.g., cost effective resource use, minimization of environmental impacts, maintaining standards of environmental management, supporting activities related to natural resources preservation, encouraging environmental preservation efforts by employees, and participation in natural resources preservation activities in the community [16]; [42]; [47]. In short, an environmental performance strategy is becoming an integral part of the overall business strategy [15]. 


\section{Relations between Environmental Performance and Competitive Performance}

Environmental performance, one of business's CSRs, can have a positive impact on the economic potential of an organization [58]. Businesses which practice appropriate environmental management can enhance their performance both in terms of efficiency and outcome of production. The businesses themselves can produce higher quality goods and services, achieve higher market share, increase their ability to enter new markets, augment employee satisfaction, and become closer to the local community [35]. Outcomes of appropriate environmental performance by a business can include greater ability to meet customer expectations and improved customer relations [33]. Businesses which practice better management of the environment have a competitive advantage over those that do not [18]; [39][59]; [60].

Document researches show that environmental performance is closely related to business performance [18] [39]; [59]; [60]. A study [30] of the relationship between environmental commitment and business performance found a strategic relationship between 2 variables: relational marketing and corporate image. That study found environmental performance has a direct positive influence on the competitive performance of a business, while corporate image is a mediating variable between environmental performance and business performance.

In the field of environmental performance measurement, researchers have studied the concept of creating indicators [54]; [57]. These researchers use 3 components in their measurement of environmental performance: reduction or elimination of hazardous wastes (RHW), lower environmental consumption (LEC), and improved environmental compliance (IEC). Based on those components, the 1st hypothesis is formulated as follows:

Hypothesis 1: Environmental Performance can have a positive effect on Competitive Performance.

\subsection{Theoretical Framework and the Theory of Green Corporate Image}

\section{Definition of Green Corporate Image}

Businesses, through their internal and external corporate image, can create good perceptions among customers, target markets, and especially stakeholders [14] which are unrelated to attributes of the business' product. Corporate image is the impression perceived by customers, the general public, and corporate staff regarding management of the business for the public benefit [28]; [41]. Corporate image can be measured by customer's perspectives [47] as well as by business activity and by the participatory behavior of staff. There are two factors involved: 1) the functional factor 
which is tangible, and 2) the emotional factor which is spiritual and intangible. Image appears in the form of feelings and attitude [1].

Based on a related study of environmental performance and corporate image, previous studies [21]; [49]; [60] found that corporate image is an important resource, an intangible asset which helps the business increase the value of its product. It can't be imitated by competitors since each firm has its own environment and its own nature of business aspects which depended upon managerial ability.

Another study [30] found that corporate image was a mediating variable between the environmental performance and the competitive performance of business organizations. For example, by saving energy an organization not only helps to reduce costs, but also improves the image of the organization in the eyes of executives, employees, and customers. It has been shown that an organization's commitment to maintaining the environment has a positive impact on the image of the organization [2].

Often the image and the reputation of an organization are the same as seen from the customer's perspective [47] as measure by the actions and behaviour of customers which contribute to improving the image and enhancing the reputation of the organization. A green corporate image is related to its attitude toward the environment and other green features that can be recognized by the organization's stakeholders [17]. Green corporate image is a reflection of the impressions of those involved in the dimension of "green reputation" and "green credibility", a green marketing concept that organizations can use in product development to create a distinct advantage for the product [60].

Green Corporate Image is measured to perceived attitudes toward the environment and green features stakeholders view as related to the dimensions of reputation and green reliability. Many scholars [12]; [17]; [60] have measured green corporate image in 3 dimensions, namely, reputation and credibility (REC), social and environmental responsibility (CSER), and the impression of a friendly organization environment (EFA).

\section{The Relationship between Green Corporate Image and Competitive Performance}

A study [30] on the relationship between corporate image and competitive performance among SMEs found that corporate image has a mediating effect between the environmental performance and the competitive performance of a business. A classic sample is conservation of energy which reduces production costs while reflecting well on management from the viewpoint of stakeholders. It has a positive effect on corporate image and the reputation of the business for environmental preservation [2], something which provides a business advantage over competitors. 
Another study [17] found a relationship between green corporate image and competitive performance. The relevance of a green corporate management image depends on the industry in which a firm operates [23]. Creating a positive green corporate image for stakeholders has become essential. If an organization operates in an environmentally sensitive industry which has business activities that are important to society and to the environment such as tourism, energy, iron and paper processing, and other industries that can potentially pollute the environment [17] for those organizations both internal and external communication play an important role in improving the image of the organization [38]. A positive green corporate image can act as a sign to its key stakeholders of a firm's commitment to protecting the environment. It is also a means to improve a firm's environmental legitimacy, its reputation, and its profitability. Therefore, the 2nd hypothesis is formulated as follows:

Hypothesis 2: Green Corporate Image has a positive effect on Competitive Performance.

\subsection{Theoretical Framework and the Theory of Competitive Performance}

\section{Definition of Competitive Performance}

Competitive performance is the organizational ability of management to have an advantage over other organizations based on sensitivity for change, especially the ability to respond to customers' needs. Businesses must be concerned with changes in globalization impact both internally and externally and cannot allow matters to proceed by themselves, but rather must actively cope with changes. Otherwise the business would not be able to survive and compete successfully with competitors [20].

Corporate performance is a result of management policy set forth at the outset, of targeted plans, and of operational business strategies which can be monitored and evaluated by customers through satisfaction, sales, profits, and other operational outcomes [56]. A business's operational performance helps the entrepreneur develop in the face of emerging competition by old and new competitors to enhance that business' competitive advantage [36].

Previous studies of environmental performance and competitive performance have described a positive relation between these two variables [11]; [27]; [30] [34], while other studies have reported a negative relationship [32]; [50]. These divergent results are due to differences in the variables which were selected to measure environmental and competitive performance [34]. 
In the business world, competition encourages most businesses to create strategies and to impose policies to compete with other businesses. It would appear that competition is fundamental to corporate efficiency, to moving a business ahead of its competitors through effective use of resources at lowest cost, i.e., giving the business a sustainable advantage [19]; [45]. There are fundamental resources which a business can acquire and/or control to support production advantages over competitors, e.g., human resources, financial resources, physical resources (raw materials), technology, communication systems, and marketing information. There are also intangible factors which business can use to develop operational strategies, e.g., the ability to change, the character of the organization, and the administrative structure of the business. These factors can be utilized to increase efficiency [22]. Results of a study [30] and further supported by other study [5] indicate that competitive performance is a result of the ability of a business to use limited resources to achieve the maximum benefits while having a minimal impact on the environment. Using resources and energy ineffectively and inefficiently could be considered unjust and unethical as those resources, which have been accumulating over a long period of time, in fact belong to others [31].

One factor in the cost of production is increasing costs of waste treatment. Producers can pass on that cost by raising the price of their products, but that lowers their competitive advantage. Businesses with better environmental performance thus have a greater competitive advantage. Many research studies have confirmed that competitiveness is positively correlated with corporate performance, especially financial performance [25]; [30]. But financial performance alone cannot adequately measure competitiveness. There are other factors, such as quality of employees, proper management, and productivity, which are also important.

In conducting this research, we used the 2-dimensional measure of competitive performance [25] of which includes financial performance (FIP) that uses financial information as a measure, e.g., sales, costs, profits received, and market share and competitive differences potential (CDP) which measures different types of marketing and technologies used by an organization to create an advantage over competitors, e.g., customer satisfaction, product and service quality, and technological advantage.

Relationship between Environmental Performance, Green Corporate Image, and Competitive Performance

A study [30] reported that environmental performance is a major factor influencing competition in business, with a positive close relationship between economic performance and strategic management in the 
development of standardization of prevention and solving of problems related to the environment. The connection between the cost of production and the cost to the environment of the production process is affected by the sustainability of development policy both directly, from economic performance, and indirectly via corporate reputation and corporate image [13]; [37]. Increasing the environmental awareness of a business which results in increase costs may create conflict indirectly with customer needs in form of higher product price but, at the same time, it may support the green corporate image. Therefore, the 3rd hypothesis is formulated as follows:

Hypothesis 3: Environmental Performance has a positive effect on Green Corporate Image.

We can conclude that there are theoretical frameworks, theories, and related researches describing the direct impacts of environmental performance on competitive performance and the indirect impacts via the green corporate image. These relations are described in the following framework.

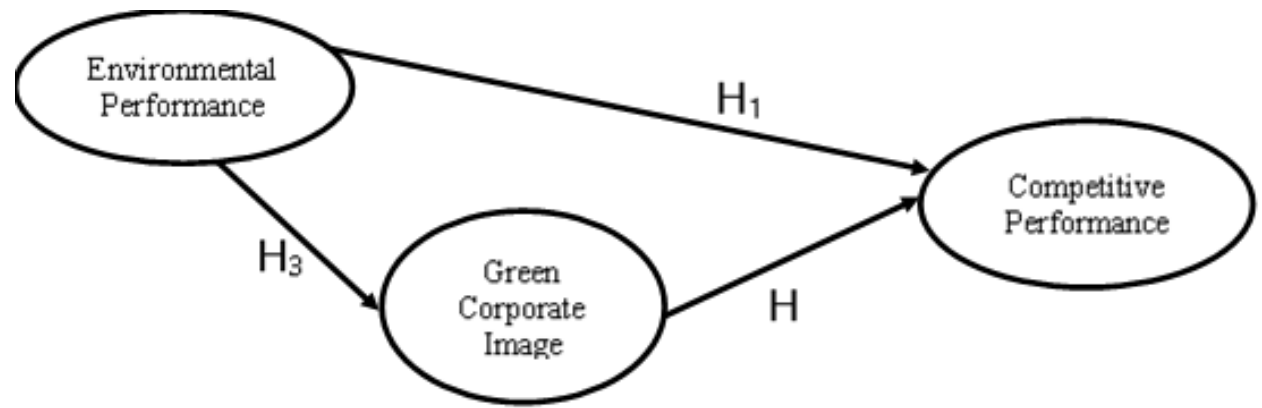

Figure 1. Conceptual framework of the relationships among Environmental Performance, Green Corporate Image, and Competitive Performance Source: Authors conception and representation

\section{Research Methods}

\subsection{Sampling and Data Collection}

The population in this research consisted of SME businesses in the food processing sector in the Bangkok metropolitan area of Thailand which had a registered capital fund of no more than 200 million baht (USD 6.5 million). A total of 7,572 SME businesses in that area were registered with the Office of Small and Medium Enterprise Promotion at the end of the year 2015 [40].

Taro's correction formula [51] was used to calculate the final sample size for continuous data at an alpha level of 0.05 and an acceptable error of 
$5 \%$. The minimum sample size requirement was calculated to be 381 . Questionnaires along with return envelopes were mailed to 400 SME senior executives or CEOs. A total of 378 questionnaires were returned, a 94.5\% response rate. The 378 questionnaires were used as a sample of analysis. The required sample size for this study was based on Structural Equation Modelling - SEM [3]. A simplified guideline for the lowest ratio of sample size to number of observed variable $(p)$ is greater than 15 [26] whereas observed variables in this study was 8 variables.

\subsection{Measurement Model}

For SEM, we identified the latent exogenous and endogenous variables. Exogenous latent variables are not influenced by other latent variables, while endogenous latent variables are dependent variables that are affected by exogenous variables. In this study, "environmental performance" was considered to be an exogenous variable, "competitive performance" was an endogenous latent variable, and "green corporate image" was a mediating variable.

The framework to be validated (Fig. 1) has 3 latent constructs, each measured by the constructs/indicators shown in Table 1. A five-point Likert scale $(1=$ "strongly disagree" and $5=$ "strongly agree") was used as the response format for each variable.

\subsection{Reliability and Validity}

Reliability analysis measures the precision or lack of distortion of indicators. Reliability is a function of the consistency, precision, and repeatability of an indicator [46]. Using the value of Cronbach's alpha, reliability of each construct/indicator included in the study was verified. In addition, item total correlation, composite reliability, and variance extracted estimates were calculated to validate the reliability of each construct/indicator through confirmatory factor analysis in the SEM model.

Cronbach's alpha was used to measure the consistency of measurements. Nunnally and Bernstein (1994) suggest that Cronbach's alpha should be at least 0.5 and preferably greater than 0.7 . Composite reliability is a measure of the internal consistency of a single construct; the reliability threshold is 0.6 [29] although a minimum of 0.7 is recommended [7]. Average variance extracted (AVE) is a measure of the internal consistency of the model; if the AVE is greater than 0.5 , the reliability is considered good [29]. The results of the reliability analysis are shown in Table 1. 


\section{Analysis and Findings}

\subsection{Descriptive Analysis}

The main purpose of descriptive analysis is to describe the basic features of the data in a study. Basic characteristics of the sample group of SMEs in the food production industry were as follows: female, 63.5\%; age above 40 years, $32.8 \%$; educational level BA level or lower, $77.5 \%$; time of experience in the food processing industry is between $5-10$ years, $33.1 \%$; and working at an executive level, $47.9 \%$. The majority, $70 \%$, had capital funds in excess of 10,000,000 million baht (300,000 USD), and 75\% employed fewer than 30 persons. Income from operation of their business was less than 5,000,000 million baht (150,000 USD) a year for 55\%. Of all the SMEs, 63\% had never received an environmental award.

\subsection{Validation of the Measurement Model and the Structural Model}

To validate the measures employed in this study, confirmatory factor analysis (CFA) was performed using AMOS version 21.0. The CFA results, summarized in Table 1, reveal a satisfactory fit for the overall measurement model $\left(\mathrm{x}^{\wedge} 2=17.092, \mathrm{p}=0.105\right.$; comparative fit index $(\mathrm{CFI})=0.997$; and root mean square error of approximation (RMSEA) $=0.038$. Each of the constructs demonstrated satisfactory reliability with composite reliability scores (CR) above 0.70 (0.889, 0.820, and 0.877). All factor loadings were significant as hypothesized at $\mathrm{p}<0.05$ and the average variance extracted (AVE) exceeded 0.50 (0.728, 0.603, and 0.782). Cronbach's alpha values ranged from 0.817 to 0.881 . All variables, means, standard deviations, and correlations are presented in Table 2 .

Table 1. Measurement Model Results

\begin{tabular}{llllll}
\hline Constructs/Indicators & $\begin{array}{l}\text { Factor } \\
\text { Loadings }\end{array}$ & $\mathrm{R}^{2}$ & $\mathrm{CR}^{2}$ & $\mathrm{AVE}^{\mathrm{b}}$ & $\begin{array}{l}\text { Cronbach's } \\
\text { Alpha }\end{array}$ \\
\hline $\begin{array}{l}\text { Competitive performance } \\
\text { (COMPERF) }\end{array}$ & & & .877 & .782 & .881 \\
\hline FIP & .869 & .755 & & & \\
CDP & .899 & .808 & & & \\
\hline $\begin{array}{l}\text { Environmental performance } \\
\text { (ENPERF) }\end{array}$ & & & .820 & .603 & .817 \\
\hline RHW & .752 & .565 & & & \\
\hline
\end{tabular}




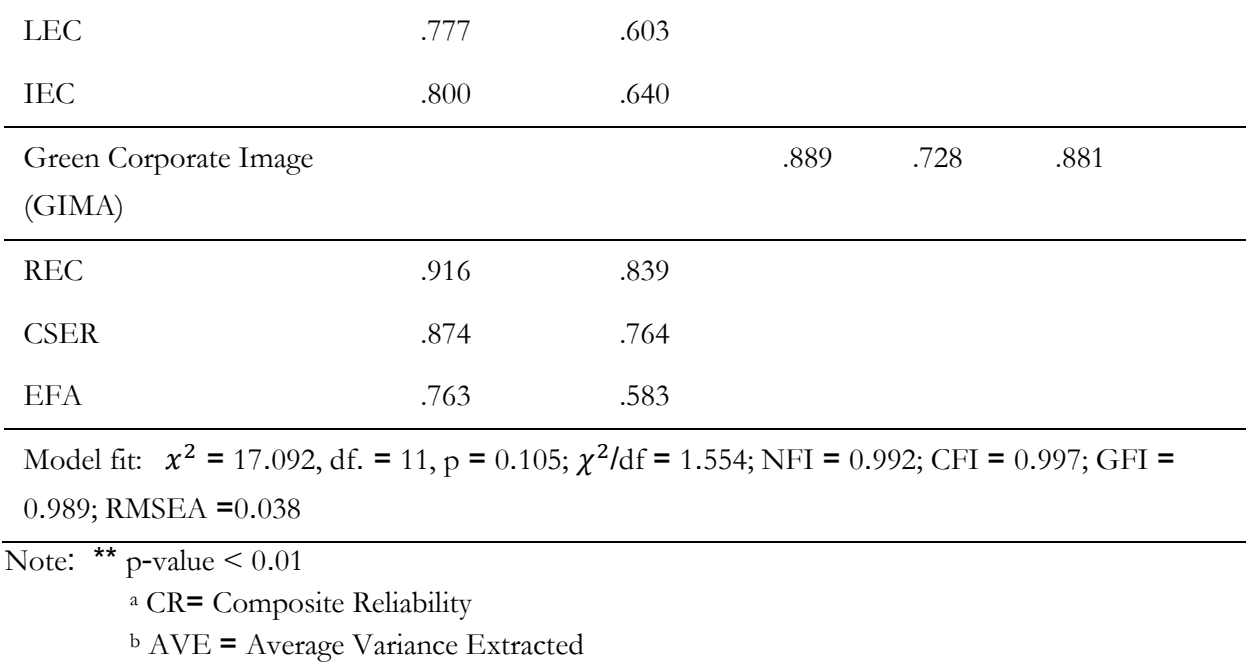

Source: Authors computation

Table 2. Correlation Analysis

\begin{tabular}{lcccccccccc}
\hline Scale & Mean & S.D. & EFA & CSER & REC & RHW & LEC & IEC & FIP & CDP \\
\hline EFA & 3.736 & .976 & 1.000 & & & & & & & \\
CSER & 3.536 & 1.037 & $.672^{* *}$ & 1.000 & & & & & & \\
REC & 3.500 & 1.004 & $.658^{* *}$ & $.802^{* *}$ & 1.000 & & & & & \\
RHW & 3.688 & 1.060 & $.522^{* *}$ & $.577^{* *}$ & $.626^{* *}$ & 1.000 & & & & \\
LEC & 3.400 & 1.016 & $.490^{* *}$ & $.611^{* *}$ & $.651^{* *}$ & $.624^{* *}$ & 1.000 & & & \\
IEC & 3.310 & 1.068 & $.513^{* *}$ & $.637^{* *}$ & $.731^{* *}$ & $.550^{* *}$ & $.625^{* *}$ & 1.000 & & \\
FIP & 3.425 & .893 & $.527^{* *}$ & $.529^{* *}$ & $.551^{* *}$ & $.354^{* *}$ & $.463^{* *}$ & $.462^{* *}$ & 1.000 & \\
CDP & 3.683 & .916 & $.605^{* *}$ & $.569^{* *}$ & $.564^{* *}$ & $.438^{* *}$ & $.453^{* *}$ & $.477^{* *}$ & $.787^{* *}$ & 1.000 \\
\hline Note: & $* *$ & p-value $<0.01$ & & & & & & & &
\end{tabular}

Source: Authors computation

\subsection{Structural Equation Modelling}

The results from the final measurement model were used to evaluate the structural model used to test the significance of the theorized relationships. The final model with path coefficients (Figure 2) indicates that the estimated model and the estimated standardized path coefficient were appropriate for evaluating the hypothesized paths. The $\chi^{2}$ statistic indicates an adequate fit with the data. All observed variable and manifest variable loadings had strong correlations $\left(\mathrm{R}^{2}\right)$ with all three latent variables. 
The values of the path estimates are shown in Figure 2. Environmental Performance significantly supports Green Corporate Image $(\beta=0.897, \mathrm{p}<0.01)$, which supports Hypothesis 3 . The expected relationship between Green Corporate Image and Competitive Performance (Hypothesis 2) was also supported by the positive standardized path coefficient $(\beta=$ 0.570, $\mathrm{p}<0.01)$. Surprisingly, the relationship between Environmental Performance and Competitive Performance was not statistically significant $(\beta=0.161, p>0.05)$, which does not support Hypothesis 1 .

These findings suggest that Green Corporate Image significantly mediates the relationship between Environmental Performance and Competitive Performance and that Environmental Performance has a strong indirect effect on Competitive Performance through Green Corporate Image $(0.897 \times 0.570=0.511)$.

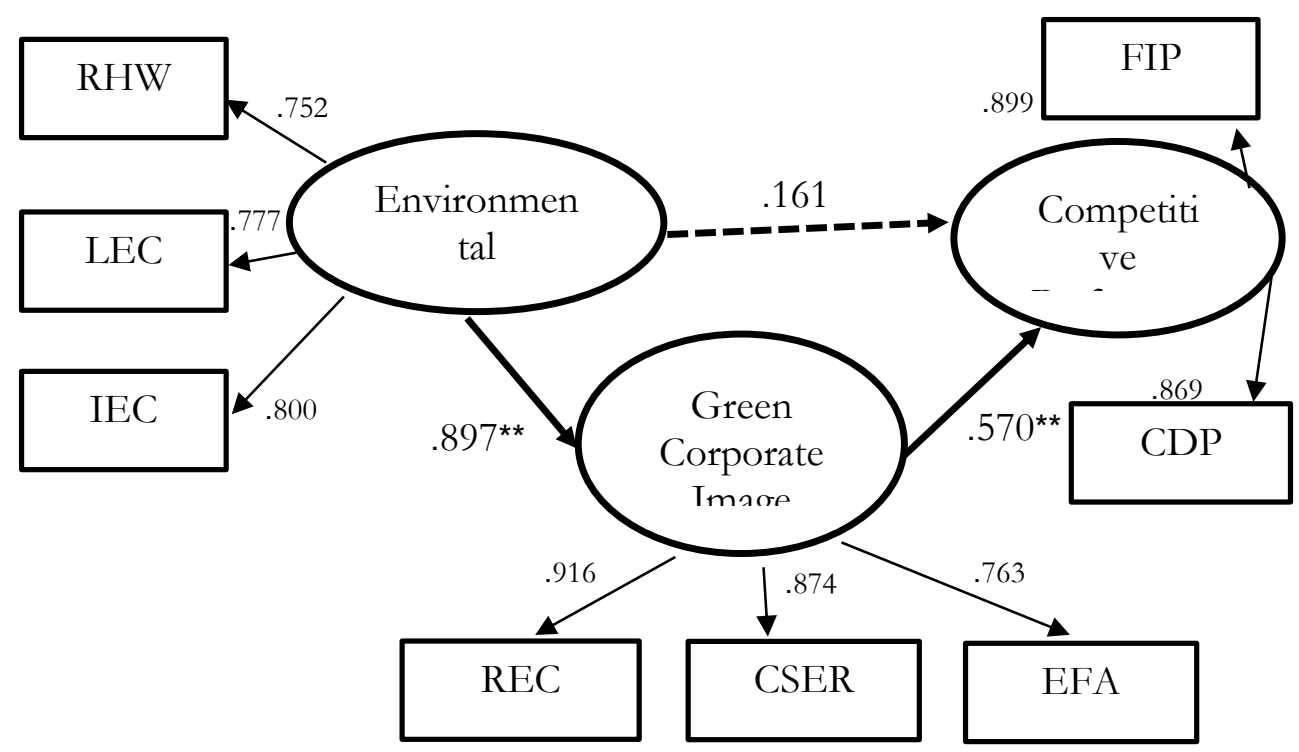

Figure 2. Path Results of the Structural Model

** Correlations between variables

Source: Authors conception and representation

\section{Discussion, Conclusion and Recommendation}

Analysis of variables and their influence on competitive performance in the food production industry found that environmental performance is statistically related to green corporate image. Moreover, environmental performance is a latent variable which has a moderate to high positive indirect effect on competitive performance via green corporate image 
because corporate performance is strategically related to corporate image [30]. Corporate social responsibility in the area of environmental performance is an important factor influencing business performance because environmental concerns provide a corporate competitive advantage [18]; [39]; [59]; [60]. Corporate environmental performance impacts development of efficiency and productivity, improving product quality, increasing productivity, increasing market share and the ability to enter new markets, as well as augmenting employee job satisfaction and increasing the ability to develop better community relations [35].

A good green corporate image is a sign that the organization desires to maintain environmental concern among stakeholders and helps to improve goodwill and the reputation of the organization. Thus, green corporate image functions to indirectly mediate relations between environmental performance and competitive performance, especially in the areas of finance and marketing [6]; [9]; [24]. It can be concluded that green corporate image is a mediating variable between environmental performance and competitive performance in the food production industry.

These findings suggest that SMEs in the food production industry should develop efficiency of performance in order to better compete with competitors, both domestic and international. The following practices are suggested.

1) SMEs in the food production industry should pay close attention to and have increased concern for environmental issues. This is especially true for environmental protection and food safety policies and regulations issued within the organization, e.g., decreasing waste and disposing of it properly, decreasing energy use, e.g., water power, electricity, gas and oil, and improving the surrounding environment in cooperation with the local community.

2) SMEs in the food production industry should increase their level of concern regarding environmental performance and should not only acting alone but should also join with other networks to help increase their competitive advantage by developing a better green image and increasing the goodwill of customers and stakeholders as a way to achieving the goal of increased sales and financial strength.

However, this study is confined in food production industry within Bangkok Metropolitan area whereas they are more of the industry in other regions of the country. In other regions there are different raw materials for food industry in cities and communities smaller than Bangkok. Large scale factories and some medium sizes export their productions mainly. 


\section{References}

[1] Ashraf AZ, Yaseen AH, Amina A. Factor analysis for an institutional image instrument. IRPNM [Internet]. 2010 [2018 October 8];7(2):157-166. Available from: https://link.springer.com/article/10.1007/s12208-010$\underline{0056-3}$

[2] Andrea R, David S, Hsin C. Small business and the environment: turning over a new leaf?. BSE [Internet]. 2010 [2019 January 30];19(5):273-288. Available from: DOI: 10.1002/bse.628

[3] Anna BC, Jason O. Best practices in exploratory factor analysis: four recommendations for getting the most from your analysis. PARE [Internet]. 2005 [cited 2018 December 19]; 10(7):1-9. Available from: DOI: $10.7275 /$ jyj1-4868

[4] Bureau of Economic Industry [Internet]. Beginning of Food and Drug Industries; [updated 2016; cited 2019 August 12]. Available from: http://www.oie.go.th/sites/default/files/attachments/IndustBasicKnowled ge/Master 1.pdf

[5] Carmelo R, Eduardo GM, Juan GC. The influence of corporate social responsibility practices on organizational performance: evidence from EcoResponsible Spanish firm. JCP [Internet]. 2016 [cited 2019 March 10];112:2870-2884. Available from: DOI: 10.1016/j.jclepro.2015.09.128

[6] Caspar R, Steen T. The impact of corporate reputation on performance: some Danish evidence. EMJ [Internet]. 2004 [2018 November 13];22(2):201210. DOI: $10.1016 /$ j.emj.2004.01.012

[7] Claes F, David FL. Evaluating Structural Equation Models with Unobservable Variables and Measurement Error. JMR [Internet]. 1981 [cited 2019 January 4]; 18(1):39-50. Available from: DOI: 10.2307/3151312

[8] David LG, Jessica K, Catherine M. An empirical study of environmental awareness and practices in SME. JBE. 2009 [cited 2019 March 20];84(1):1-19. Available from: DOI: 10.1007/s10551-008-9672-9

[9] Deborah G. Reputation Orientation Improving Marketing Performance through Corporate Reputation Building. MIP. 2015 [cited 2019 January 27];33(5):784-803. Available from: DOI: 10.1108/MIP-2013-0183

[10] Dow Jones Industrial Average [nternet]. Environmental, Social and Governance Investing; [updated 2018; cited 2019 August 9]; Available from: https://www.dowjones.com/insight/esg-investing-analytic/

[11] Emilio GG, Jose CL, Javier M-del-R. Environmental Performance and Spillover Effects on Productivity: Evidence from Horticultural Firms. JEM [Internet]. 2008 [cited 2018 December 15];88(4):1552-1561. Available from: DOI: $10.1016 /$ j.jenvman.2007.07.028 
[12] Eva M, Jose MP. Influence of Corporate Image on Brand Extensions: A Model Applied to the Service Sector. JMC [Internet]. 2005 [cited 2019 February 17];11(4):263-281. Available from: DOI: $10.1080 / 13527260500167264$

[13] Francesco C, Pierpaolo P, Barbara S. Investigating Corporate Social Responsibility in Supply Chains: A SME Perspective. JCP [Internet]. 2008 [cited 2018 November 10];16(15):1579-1588. Available from: DOI: 10.1016/j.clepro.2008.04.016

[14] Grahame RD. Corporate Reputations: Strategies for Developing the Corporate Brand. London. Kogan Page; 2004, 256 p.

[15] Grace TS, Hengky L. Linking Environmental Strategy to Environmental Performance: Mediation role of environmental management accounting. SAMPJ [Internet]. 2017 [2019 August 14];8(5):595-619. Available from: DOI: $10.1108 /$ sampj-08-2016-0046

[16] International Organization for Standardization [Internet]. ISO: 26000; [updated 2010; cited 2019 August 12]; Available from: https://www.iso.org/files/live/sites/isoorg/files/store/en/PUB100259.pdf

[17] Javier AS, Gregorio M-de-C, Jose ENL. Green corporate image: moderating the connection between environmental product innovation and firm performance. JCP [Internet]. 2014 [cite 2019 March 17];83:356-365. Available from: DOI: 10.1016/j.jclepro.2014.07.059

[18] Javier GB, Oscar GB. Environmental Proactivity and Business Performance: An Empirical Analysis. Omega [Internet]. 2005 [cited 2019 June 24];33(1):115. Available from: DOI: 10.1016/j.omega.2004.03.002

[19] Jay BB. Firm resources and sustained Competitive advantage. JM [Internet]. 1991 [2018 October 9];17(1):99-120. Available from: DOI: 10.1177/014920639101700108

[20] Jay BB. Resource-based theories of competitive advantage: A ten-year retrospective on the resource-based view. JM [Internet]. 2001 [cited 2019 January 10]; 27(6):643-650. Available from: DOI: $10.1177 / 014920630102700602$

[21] Jay BB, Delwyn NC. Resource Based Theory: Creating and Sustaining Competitive Advantage. Oxford: Oxford University Press; 2007 [cited 2019 May 8].

[22] Jay BB, Mike W, David JK. The future of resource-based theory: Revitalization or decline? JM [Internet]. 2011 [cited 2019 January 25];37(5):1310-1311. Available from: DOI: 10.1177/0149206310391805 
[23] Jeff F. Stakeholder influence strategies. AMR [Internet]. 1999 [cited 2019 February 1]; 24(2):191-205. Available from: DOI:

10.5465/amr.1999.1893928

[24] Jeremy G, Paul KS. Do Customer Satisfaction and Reputation Mediate the CSR-FP Link? Evidence from Australia. AJM. 2012 [cited 2019 March 9]; 37(2):211-229. Available from: DOI: 10.1177/0312896211432941

[25] Jesus HM, Manuel LJ, Isabel MC, Domingo MM. Relationship between Corporate Social Responsibility and Competitive Performance in Spanish SME: Empirical Evidence from a Stakeholders' Perspective. BBQ BRQ [Internet]. 2016 [cited 2019 April 19];19(1):55-72. Available from: DOI: 10.1016/j.brq.2015.06.002

[26] Joseph FH, William CB, Barry JB, Rolph EA, Ronald LT. Multivariate Data Analysis. 6th edition. New Jersey: Pearson Education; 2006. 899 p.

[27] Juan AAC, Enrique RL. Proactive Corporate Environmental Strategies: Myths and Misunderstandings. LRP [Internet]. 2007 [cited 2018 September 2];40(3):357-381. Available from: DOI: 10.1016/j.lrp.2007.02.008

[28] Kevin LK. Branding and brand equity. In A. Barton. Weitz \& Robin Wensley (Eds.), Handbook of Marketing. UK: London SAGE Publications Ltd.; 2002. p. 151-178.

[29] Larry H. A Step-by-Step Approach to Using the SAS System for Factor Analysis and Structural Equation Modeling. Cary NY: SAS Institute; 1994. $608 \mathrm{p}$.

[30] Manuel LJ, Herrera MJ, Domingo MM, Maria PLS. Competitiveness and Environmental Performance in Spanish Small and Medium Enterprises: Is there a Direct Link?.JCP. 2015 [cited 2018 November 15];101:26-37. Available from: DOI: 10.1016/j.jclepro.2015.04.016

[31] Manuel GV. Business Ethics - Concepts and Cases. 7th edition. UK: Pearson International; 2014. 155 p.

[32] Marcus W. How to reconcile environmental and economic performance to improve corporate sustainability: Corporate environmental strategies in the European paper industry. JEM [Internet]. 2005 [2018 October 19];76(2):105118. Available from: DOI: $10.1016 /$ j.jenvman.2004.11.021

[33] Martin G, Timothy B. Company environmental performance and consumer purchase intentions. JBR. 2013 [cited 2018 November 8];66(10):1945-1953. Available from: DOI: 10.1016/j.jbusres.2013.02.017

[34] Maria DLG, Enrique CC, Jose FMA. Complementary Resources and Capabilities for and Ethical and Environmental Management: A Qual/Quan Study. JBE [Internet]. 2008 [cited 2019 April 19];82(3):701-732. Available from: DOI: $10.1007 / \mathrm{s} 10551-007-9587-\mathrm{x}$ 
[35] Michelle M, Seyhmus B. Hotel guests' preferences for green hotel attributes. CHQ [nternet]. 2011 [cited 2019 May 19];52(3):302-311. Available from: DOI: $10.1177 / 1938965511409031$

[36] Michael EP. Competitive Strategy. New York: Free Press; 1980. 396 p.

[37] Michael EP, Mark RK. The competitive advantage of corporate philanthropy. HBR [Internet]. 2002 [cited 2019 April 23];80(12):57-68. Available from:

https://www.academia.edu/39670432/The Competitive Advantage of Co rporate Philanthropy

[38] Monica S, Geoffrey D. Green Companies or Green Con-Panies: Are companies really Green, or Are They Pretending to be?. BSR [Internet]. 2005 [2019 April 15];110(2):117-157. Available from: DOI: 10.1111/j.00453609.2005.00007.x

[39] Nei-Jen C, Cher-Min F. Green Product Quality, Green Corporate Image, Green Customer Satisfaction, and Green Customer Loyalty. AJBM [Internet]. 2010 [cited 2018 August 23];4(13):2836-2844. Available from: DOI: $10.5897 /$ AJBM.9000310

[40] OSMEP [Internet]. Trends of the Export, Import and the Growth Rate of the SMEs. 2012-2016. [cited 2018 July 25]. Available from: http://www.sme.go.th/eng/

[41] Philip K. Marketing Management. 10th edition. New Jersey: Prentice-Hall; 2000. 533 p.

[42] Puneeta G. Triple bottom line reporting: An analytical approach for corporate sustainability. JFAM [Internet]. 2010 [cited 2019 May 8];1(1):27-42. Available from: http://eds.a.ebscohost.com/eds/detail/detail?vid=0\&sid=98470970-75aa4ebe-a2817a263a1c9b87\%40sessionmgr4007\&bdata $=$ JnNpd\%20GU9ZWRzL $\% 20 W x$ $\mathrm{pdmU} \% 3 \mathrm{~d} \# \mathrm{AN}=61996575 \& \mathrm{db}=\mathrm{bsx}$

[43] Pratima B, Kendell R. Why companies go green: a model of ecological responsiveness. AMJ [Internet]. 2000 [cited 2018 September 16];43(4):717736. Available from: DOI: $10.2307 / 1556363$

[44] Qinghua Z, Joseph S, Kee-hung L, Yong G. The role of organizational size in the adopting of green supply chain management practices in China. CSREM [Internet]. 2008 [cited 2019 April 15];15(6):322-337. Available from: DOI: $10.1002 /$ csr.173

[45] Raphael A, Paul JHS. Strategic assets and organizational rent. SMJ [Internet]. 1993 [2019 January 21];14(1):33-46. Available from: DOI: $10.1002 /$ smj.4250140105 
[46] Rex BK. Principles and Practice of Structural Equation Modeling. 3th edition. NY: The GuilFord Press; 2011. 427 p.

[47] Robert R, Ali Q, Byron K. Applying a consumer perceptual measure of corporate social responsibility: a regional Australian perspective. JCC [Internet]. 2008 [2019 July 3];29(Spring):61-74. Available from: https://pdfs.semanticscholar.org/dd4e/65864e4b9c11971a04004b9500bd61 8be5d5.pdf

[48] Sanit K, Viroj J, Jantana S. Component and Pattern of Strategic Corporate Social Responsibility: Hotel Business in Thailand. Journaldtc [Internet]. 2018 [cited 2019 September 10];11(special):171-185. Available from: https://so01.tci-thaijo.org/index.php/journaldtc/article/view/136163

[49] Sarah R. Supply chain specific? Understanding the patchy success of ethical sourcing initiatives. JBE [Internet]. 2003 [2019 June 8];44(2/3):159-170. Available from https://link.springer.com/content/pdf/10.1023/A:1023395631811.pdf

[50] Sharon L, Eitan N. Standardization and discretion; Does the environmental standard ISO 14001 lead to performance benefits?. IEEE TEM [Internet]. 2006 [cited 2019 June 3];53(4):508-519. Available from: DOI: 10.1109/TEM.2006.883704

[51] Taro Y. Statistics: An Introductory Analysis. 3rd edition. New York: Harper \& Row; 1973. 1130 p.

[52] Thailand Board of Investment [Internet]. Thailand Food Industry; [updated 2016; cited 2019 August 12]. Available from:

https://www.boi.go.th/index.php?page=business opportunities detail\&topi c $\mathrm{id}=117522$

[53] Thaipublica [nternet]. 5 hottest business sustainability trends: The Path to Sustainability; [updated 2011; cited 2018 October 10]. Available from: https://thaipublica.org/2011/10/the-path-to-sustainability/

[54] Tzu-Yun C, Hing Kai C, Fiona L, Sai HC. The influence of greening the suppliers and green innovation on environmental performance and competitive advantage in Taiwan. TRP-E [Internet]. 2011. [cited 2018 September 16];47:822-836. Available from: DOI: 10.1016/j.tre.2011.05.016

[55] Udemy [Internet]. 8 Consumer Rights and Responsibilities: How to Be Protected; [updated 2020; cited 2020 April 10]; Available from: https://blog.udemy.com/consumer-rights-and-responsibilities/

[56] Wanchai K, Viroj J. The Impact of Customer Relationship Management on Customer Responsiveness and Business Performance of Electronic Commerce in Thailand. JAM [Internet]. 2014 [cited 2019 May 8];8(2):53-66. 
Available from:

https://www.mis.ms.su.ac.th/MISMS01/PDF02/200 20190615 j 27.pdf

[57] William QJ, Thomas JD. Performance implications of incorporating natural environmental issues into the strategic planning process: An empirical assessment. JMS. 2002 [cited 2019 February 22];35(2): 241-262. Available from: DOI: 10.1111/1467-6486.00092

[58] Yavuz A, Cemil K, Mehmet FA, Atif A. The relationships between corporate social responsibility, environmental supplier development, and firm performance. JCP [Internet]. 2016 [cited 2018 August 11];112(3): 1872-1881. Available from: DOI: 10.1016/j.jclepro.2014.08.090

[59] Yu-Shen C, Shyh-Bao L, Chao-Tung W. The Influence of Green Innovation Performance on Corporate Advantage in Taiwan. JBE [Internet]. 2006 [cited 2019 March 4]; 67(4): 331-339. Available from: DOI: 10.1007/s10551-0069025-5

[60] Yu-Shen C. The Driver of Green Innovation and Green Image - Green Core Competence. JBE [Internet]. 2008 [cited 2018 November 11];81(3):531-543. Available from: DOI: 10.1007/s10551-007-9522-1 